\title{
A Celtic Gloss in the HesyChIAN LeXICON
}

\author{
KRZYSZTOF TOMASZ WITCZAK
}

\section{Introduction}

The well known lexicon, prepared by Hesychios of Alexandria (c. 400$500 \mathrm{AD}$ ), contains a number of glosses recorded not only on the basis of various dialects of the ancient Greek, but also on the basis of various languages of ancient Europe, Asia and Africa. There are also glosses

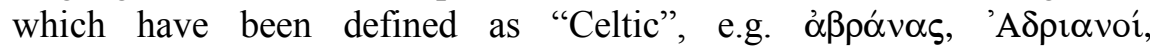

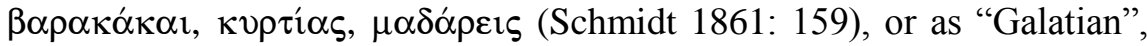

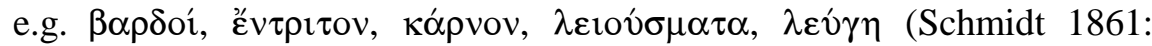
157).

However, most Hesychian glosses appear with no ethnic designation. Some of them can be convincingly treated as Celtic (especially Galatian) terms. There is also such instance, which is connected with the following gloss:

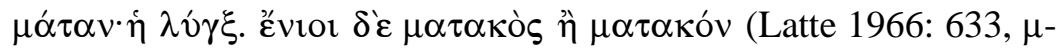
391).

mátan [means] a she-lynx. Some [call lynx] matakós or matakón

The heading $\mu \alpha \dot{\alpha} \tau \alpha \nu$ is actually defined as 'a female lynx' (Gk. $\dot{\eta} \lambda \hat{\gamma} \gamma \xi)$, i.e. a short-tailed wild animal of the Felidae family, noted for its keen sight (Hornby 1981: 509). Also two alternative forms $\mu \alpha \tau \alpha \kappa o ́ s$ (originally 'a male lynx') and $\mu \alpha \tau \alpha \kappa o ́ v$ (probably 'a small or young lynx'), which belong undoubtedly to the same idiom, are given by Hesychios of Alexandria.

\section{Celtic evidence.}

Three Hesychian names for 'lynx' seem to possess exact and convincing equivalents only in the Celtic insular languages.

1.1. Celtic *mat- 'a kind of predator' (1. lynx, 2. bear, 3. fox, 4. dog), *matākós m. id. (1. lynx, 3. fox).

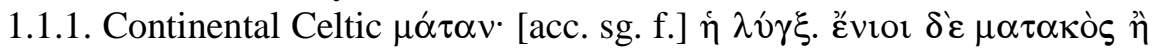
$\mu \alpha \tau \alpha \kappa o ́ v$. Further Continental Celtic cognates are extremely uncertain: Cib. matu- 'a bear' (?) appears in the first Botorrita inscription (v. 6): tiris matus tinatuz (translated as 'drei Bären sollen saugen' by Schmidt 1976a: 365; 1976b: 57; Toporov 1986: 219 accepts such interpretation). 
1.1.2. OIr. math (gen. sg. matho) m. ( $u$-stem) 'a bear' $(<$ Celt. Goid. *matu-); Scottish Gaelic mathan, mathon m. 'a bear' (< Celt. Goid. *matagnos) (Forbes 1905: 66; Owen 1993: 78), also Sc. Gael. mathghamhuin 'a bear' (Forbes 1905: 66), Early Ir. mathgaman id. (Macbain 1998: 244); 1.1.3. OW. madawg, W. madog m. 'a fox' (< Celt. Britt. *matākos); W. madyn m. 'a fox', maden f. 'a small she-fox, a vixen' ( $<$ Celt. Britt. *matinos m. vs. *matinā f.) (Holder 1904 [1962]: II 479; Evans 1979: 124);

1.1.4. Ir. matad 'a dog' (Polomé 1998: 669); Sc. Gael. madadh m. 'a dog', esp. mastiff, madadh-allaidh 'a wolf' (lit. 'a wild dog'), madadh-ruadh m. 'a fox' (lit. 'a red-haired dog') (Forbes 1905: 160). The relation of the last group (1.1.4) is uncertain. Some linguists derive it from the IndoEuropean root *masd- (so Macbain 1998: 238) and not from *mat-.

1.2. The animal name in question was highly popular in the Celtic languages, as can be seen from the following personal names (PNs):

Gaulish PN Matacus = Old Brittonic PN Matucus, Old Welsh PN Matauc, Matoc, Breton PN Matoc, later Matec (< CC. *Matākos), see Holder (1904 [1962]: II 457, 480).

Gaulish PN Matinus m., Matina f. (<CC. *Matinos m., $-\bar{a} \mathrm{f} .$, cf. W. madyn m. 'a fox', maden f. 'a small female fox, a vixen'), cf. Holder (1904 [1962]: II 460).

Gaulish, Old Brittonic PN Matugenus m., Hispano-Celtic PN Matugenus, Matucenus, Old Irish PN Mathgen, Old Welsh PN Madyein (< CC. *Matu-genos, lit. 'a son of bear'), cf. Holder (1904 [1962]: II 480481), Evans (1979: 124) and Vallejo Ruiz (2005: 350-354).

Old Welsh PN Matgueith (< CC. *Matu-vektos), see Holder (1904 [1962]: II 479).

1.3. Comments: Oštir (1930: 73) treated the Hesychian names for 'lynx',

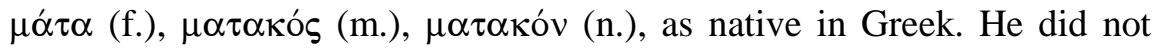
connect them with the Celtic names. Also, Celtic scholars (cf. Holder 1904 [1962]: II 479; Evans 1979: 124) give no reference to the Hesychian gloss.

\section{Ethnic designation}

The Celtic origin of the Hesychian gloss seems to be relatively certain for three reasons.

Firstly, none of non-Celtic Indo-European languages know an animal term which derives from *mat-. This root is limited only to the Celtic language world.

Secondly, the archetype *matākós appears both in the Brittonic common names (see OW. madawg, W. madog m. 'a fox') and the Common Celtic proper names (cf. Gaulish PN Matacus $=$ OBritt. PN 
Matucus, OW. PN Matauc, Matoc, Bret. PN Matoc, Matec). The same item is, with no doubt, reflected in the Hesychian gloss in question

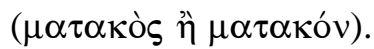

Thirdly, the Hesychian forms $\mu \alpha \tau \alpha \kappa o ́ \varsigma$ (m.) and $\mu \alpha \tau \alpha \kappa o ́ v$ (n.), as well as Old Welsh madawg, Welsh madog m. 'a fox', were formed by means of the identical suffix $*_{-} \bar{a} k o-$. The Celtic origin of the gloss is therefore confirmed by its word-formation structure.

The Gaulish personal name Matacus seems to demonstrate the existence of the proper term *matākos denoting 'lynx' (or a similar animal) in Continental Celtic (as suggested by the Hesychian gloss in question). Also, the related proper names of Celtic origin, attested in Gaul and Celtiberia (e.g. Gaulish PN Matinus, Hispanic Celtic Matugenus), confirm the correctness of the Hesychian gloss in question.

\section{Semantic questions}

The insular Celtic languages demonstrate three various meanings: 'a bear', 'a fox' and 'a dog'. The semantics of the Hesychian gloss ('lynx') is completely different. However, the semantic aspects can be easily explained by the well known fact that lynx was (and is) absent in the British Islands. Mallory and Adams (1997: 360) stress that "the lynx was died out in the British Isles quite early in the prehistoric period, the most recent find being only of Mesolithic date". In this situation the original term for 'lynx', a big and strong predator, might be easily transferred onto 'a bear' (in the Goidelic dialects) or 'a fox' (in the Brittonic dialects). As lynx inhabits the Continental European area (beginning from the Iberian Peninsula in the west $\left.{ }^{1}\right)$ as well as the Asia Minor, the Common Celtic term for 'lynx' (which I identify with the root *mat-) should be preserved in the Continental Celtic languages such as Galatian, Gaulish or Celtiberian. If the Hesychian gloss indicates the meaning of 'lynx', then there is a justifiable reason to think that the Common Celtic root *matmeant originally nothing other than 'lynx'. All the meanings attested in the Insular Celtic languages ('bear'; 'fox'; 'dog, mastiff') must be treated as secondary.

\section{Etymology}

Vendryes (1959: M-24) connects OIr. math m. ( $u$-stem) 'ours' ('a bear') with the Celtic adjective *mati- ( $i$-stem) 'bon, favorable' ('good, favourable') (cf. OIr. maith adj. 'bon, excellent, avantageux' ('good, excellent'), n. 'le bien, l'avantage' ('good, fortune') (Vendryes 1959: M-12).

\footnotetext{
${ }^{1}$ The Iberian Peninsula is the homeland of Spanish lynx or Iberian lynx or Pardel lynx (Lynx pardina), slightly smaller and more heavily spotted than the Northern lynx (Burton 1984: 141-142; Arnold, Corbet, Ovenden 1989: 53; Dobroluka 1998: 96). It is generally treated as a local species.
} 
He suggests that "l'ours aurait été désigné par une épithète flatteuse, comme cela se produit pour d'autres animaux de l'époque préhistorique". The original IE name for 'brown bear', PIE $* h_{2 f}$ t kos (o-stem), is preserved as *artos 'bear' in Common Celtic (cf. OIr. arth m. 'a bear'). The removal of the original term *artos was probably caused by a taboo. According to Mallory, Adams (1997: 55), the same process may be observed in the Germanic (Eng. bear, Germ. Bär orig. 'brown animal'), Slavic (Russ. medved', Pol. niedźwiedź orig. 'honey-eater') and Baltic languages (Lith. lokŷs, Latv. lâcis, OPruss. clokis orig. 'shaggy animal').

Toporov (1986: 220) compares Celtiberian matu- (with the alleged meaning 'bear') with Latv. mats (pl. mati) 'hair', matains adj. 'hairy, covered with hair', matiňs 'a single hair', Russ. mot' 'прядь волос' ('lock of hair'). The Latvian word for 'hair' seems to be related to Toch. B matsi 'Haupthaar' ('(human) head hair'). Thus, 'a hairy (shaggy) animal' appears to be a taboo word for 'bear'.

The internal Celtic etymology, proposed by Vendryes, seems more acceptable than Toporov's explanation. What is more, Toporov's comparison prefers the original semantics of 'bear' (or, perhaps, of 'fox') and excludes the original meaning of 'lynx' (the Eurasian lynx has a relatively short, reddish or brown coat, especially during the summer). It is quite appropriate that lynx might have been once called 'a good, favourable one', itself being a wild animal that avoids people.

It cannot be excluded that the Common Celtic term for 'lynx' (CC. *matākos and so on) was originally motivated by the substrate (perhaps Celtic) verbal root *mat- 'to kill', cf. Port. Sp. matar 'to kill, hurt, harm, wound' (Corominas, Pascual 2000: 878-881; Meyer-Lübke 1935: 442-443) and Gaulish matara, mataris f. 'a Celtic javelin or pike' (Billy 1993: 104). In fact, lynx as a big carnivorous predator, which hunts hares, rodents and birds, may be called 'a killer'.

\section{Galatian influence (?)}

Though the ancient Greeks were well acquainted with the Gauls and the Celtiberians, they also had somewhat intensive contacts with the Galatians. There are at least ten Celtic glosses in the Hesychian lexicon and five of them (i.e. 50\%) are defined as "Galatian". Also, the remaining Hesychian glosses of Celtic origin may directly derive from a Galatian source.

There is also the following case connected with the gloss below:

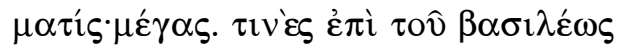

(Schmidt 1861: 76, $\mu$-404; Latte 1966: 633, $\mu-402$ ) matís [means] 'great' (strong, mighty). Some [say so] about the king. 
This adjective is completely absent in all the Greek literary texts. That is why the gloss is said to represent a foreign non-Greek word. In my opinion, it is possible to connect the gloss in question ( $\mu \alpha \tau$ í $\varsigma$ adj. 'great, strong, mighty') with the Old Irish adjective maith ( $i$-stem) 'good, excellent, profitable, wealthy', MW mad 'fortunate, good', MCo. mas, MBret. mat, Bret. mad 'good' and Gaulish mat attested in the Coligny inscription (< CC. *matis adj., $i$-stem) (Schrijver 1995: 175). The gloss should be treated as a Continental Celtic word, possibly a Galatian one. The same suggestion is given by Ranko Matasović (2009: 259): "Beyond Celtic, Gr. matis 'great' (Hesych.) is uncertain (it is not even ascertained that the word is Greek, it might be Galatian)".

To the best of my knowledge, there is no adjective in the attested Indo-European languages which is similar to *matis. It is possible to suggest that the Hittite adjective lazzi- 'good, fortunate' (Güterbock, Hoffner 1980: 50), which can be securely derived from the Anatolian *latis of the same meaning, may be somewhat related to the Celtic matis 'good, excellent, profitable, wealthy'.2 Appropriate comparanda can be drawn from the Hitt. $\overline{\bar{e}}$ 'not' (prohibitive particle) that corresponds to PIE. *mē id. (Kloekhorst 2008: 523, cf. Skt. $m \bar{a}$, Gk. $\mu \eta$, Arm. $m i$, Toch. AB $m \bar{a})$. However, the initial phoneme $l$ - in Anatolian hardly agrees with $m$ in Common Celtic, as well as with $\mu$ - in the Hesychian gloss in question.

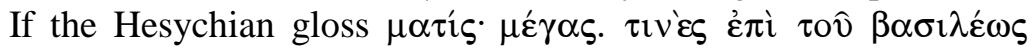
actually refers to the Celtic adjective matis 'good, excellent, profitable,

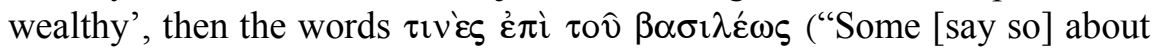
the king") seem to denote the Galatian kings called "great" after the ancient Greek phrase ó $\mu \varepsilon \dot{\varepsilon} \alpha \varsigma \beta \alpha \sigma \imath \lambda \varepsilon v$ v 'great king'.

It is further probable that these two Hesychian glosses $\mu \alpha \tau \alpha v^{\cdot} \dot{\eta}$

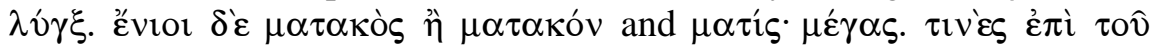
$\beta \alpha \sigma \imath \lambda \dot{\varepsilon} \omega \varsigma$ were taken from the same literary source, which explained the titles of the Galatian kings.

University of Łódź

\footnotetext{
${ }^{2}$ Note that Puhvel (2001: 68-74) and Kloekhorst (2008: 522-523) explain the origin of the Hittite adjective lazzi- in a different way.
} 


\section{References}

Arnold, N., Corbet, G., Ovenden, D., 1989, A Handbook to the Wild Animals of Britain and Europe, London: Treasure Press.

Billy, P.-H., 1993, Thesaurus Linguae Gallicae, Hildesheim-New York: Olms-Weidmann.

Burton, M., 1984, Guide to the Mammals of Britain and Europe, London: Treasure Press.

Corominas, J., Pascual, J. A., 2000, Diccionario crítico etimólogico castellano e hispánico, vol. 3 (G-MA), Madrid: Gredos.

Dobroruka, L. J., 1998, Mammals, Prague: Blitz Editions.

Evans, D. E., 1979, 'On the Celticity of Some Hispanic Personal Names', in: A. Tovar, M. Faust, F. Fischer \& M. Koch, eds., Actas del II Coloquio sobre lenguas y culturas prerromanas de la Península Ibérica (Tübingen, 17-19 Junio 1976), Salamanca: Ediciones Universidad de Salamanca, 117-129.

Forbes, A. R., 1905, Gaelic Names of Beasts (Mammalia), Birds, Fishes, Insects, Reptiles, Etc., Edinburgh: Oliver and Boyd.

Güterbock, H. G., Hoffner, H. A., 1980, The Hittite Dictionary of the Oriental Institute of the University of Chicago, vol. 1, fasc. 1, Chicago: The Oriental Institute of the University of Chicago.

Holder, A., 1904 [1962], Alt-celtischer Sprachschatz, Zweiter Band (I-T). Leipzig: Teubner. Reprinted in 1962 in Graz: Akademische Druck u. Verlagsanstalt.

Hornby, A. S., 1981, Oxford Advanced Learner's Dictionary of Current English, vol. 2 (L-Z), Oxford-Warszawa: Oxford University Press, PWN - Polish Scientific Publishers.

Kloekhorst, A., 2008, Etymological Dictionary of the Hittite Inherited Lexicon, Leiden - Boston: Brill.

Latte, K., ed., 1966, Hesychii Alexandrini Lexicon, vol. 2 (E-O), Hauniae: Ejnar Munksgaard.

Macbain, A., 1998, Etymological Dictionary of Scottish-Gaelic, New York: Hippocrene Books.

Mallory, J. P., Adams, D. Q., 1997, Encyclopedia of Indo-European Culture, London and Chicago: Fitzroy Dearborn Publishers.

Matasović, R., 2009, Etymological Dictionary of Proto-Celtic, Leiden Boston: Brill.

Meyer-Lübke, W., 1935, Romanisches etymologisches Wörterbuch, Heidelberg: Carl Winter.

Oštir, K., 1930, Drei vorslavisch-etruskische Vogelnamen (astrębъ ::

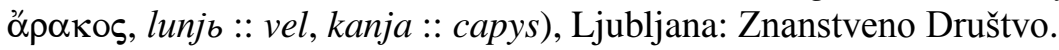


Owen, R. C., 1993, The Modern Gaelic-English Dictionary (Am Faclair ur Gaidhlig-Beurla), Glasgow: Gairm Publications.

Polomé, E. C., 1998, 'Some Reflections on Indo-European Animal Names', in: P. Anreiter, L. Bartosiewicz, E. Jerem \& W. Meid, Man and the Animal World. Studies in Archaeozoology, Archaeology, Anthropology and Palaeolinguistics in memoriam Sándor Bökönyi, Budapest: Archaeolingua, 669-674.

Puhvel, J., 2001, Hittite Etymological Dictionary, vol. 5 (Words beginning with L), Berlin - New York: Mouton de Gruyter.

Schmidt, K. H., 1976a, 'Historisch-vergleichende Analyse des der keltiberischen Inschrift von Botorrita zu Grunde liegenden Morpheminventars', in: A. Morpurgo Davies \& W. Meid, Studies in Greek, Italic and Indo-European Linguistics offered to Leonard R. Palmer On the Occasion of his Seventieth Birthday, Innsbruck: Institut für Sprachwissenschaft der Universität Innsbruck, 359-371.

Schmidt, K. H., 1976b, 'Der Beitrag der keltiberischen Inschrift von Botorrita zur Rekonstruktion der protokeltischen Syntax', Word 28(1-2), 1976, 51-62.

Schmidt, M., ed., 1861, Hesychii Alexandrini lexicon, vol. III ( $\Lambda$-P), Ienae: Sumptibus Frederici Maukii.

Schrijver, P., 1995, Studies in British Celtic Historical Phonology, Amsterdam - Atlanta: Rodopi.

Toporov, V. N., 1986, 'Kel'tibyerskaya nadpis' iz Bottority v svyete balto-slavyanskogo sravnyeniya' [The Celtiberian Inscription from Botorrita in the light of the Balto-Slavic comparison], Balto-slavyanskiye issledovaniya 1984 [Balto-Slavic Studies 1984], 209-224.

Vallejo Ruiz, J. M., 2005, Antroponimia indígena de la Lusitania romana, Vitoria-Gasteiz: Servicio Editorial de la Universidad del País Vasco.

Vendryes, J., 1959, Lexique étymologique de l'irlandais ancien, vol. 2 (M-P), Dublin: Dublin Institute for Advanced Studies, Paris: Centre National de la Recherche Scientifique. 